\title{
Constructing Meaning through Visual Spatial Activities:
}

\author{
An ALAN Grant Research Project
}

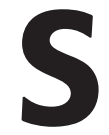

hamatee stood in front of the class, cardboard box in hand, explaining how her model was related to the book, Mick Harte Was Here (Barbara Park, Random House, 1996). It was a recreation of the scene when Phoebe, Mick's sister, was speaking at his funeral. This was the culminating project of a six-week unit using literature circles. The project was minimal with little detail. In fact, if Shamatee had not explained that it was a model of the church, there would have been no way of identifying it. Her accompanying writing, however, told a different story. In it she explained how the book, and this scene in particular, had reminded her of her own brother who died in a motorcycle accident. Shamatee empathized with Phoebe and could feel her sadness and fear as she spoke at her own brother's funeral. The black, dark walls spoke to her intense emotions when she recalled this event because of reading the book. Shamatee understood Phoebe's pain and loss. Her connections to the book were real; her model was, in fact, a three-dimensional object showing in-depth meaning-making from this book. In general, Shamatee did not have a great track record of completing written assignments as they were usually minimal with little evidence of understanding or depth. But here was a piece of writing, almost two pages in length, discussing why she chose to create this scene and what it meant to her. The model was a bridge between her reading of the book and her writing about the book.

This experience made me wonder about how students construct meaning from a book. In particular, how do students construct meaning through visual spatial activities such as models and other art forms? This article describes a study in which I sought to answer that question by working with ten sixth-grade struggling readers responding to short stories using visual spatial activities. Research shows that alternate ways of constructing meaning are infrequently used in reading classrooms (Smagorinsky; Smagorinsky \& Coppock 1994). The norm in most reading and language arts classes is to encourage students to use the mode of writing to show what they know. However, according to Armstrong, "linguistic intelligence is not the only building block for reading competence" (79). I cannot help but wonder what amazing examples of constructing meaning we are missing in our classrooms when we limit our students' mode of communication to writing. Let me state that there is nothing wrong with using written expression in the reading classroom; the problem arises when that mode is the only option available.

\section{Reader Response Theory}

This study is built upon Rosenblatt's (1978) Reader Response Theory in which she speaks of reading as a transaction, a type of living through text with two different ways of transacting with textaesthetic and efferent. "Sensing, feeling, imagining, thinking, synthesizing the states of mind, the reader who adopts the aesthetic attitude feels no compulsion other than to apprehend what goes on during this 
process" of reading (26). Contrary to transmission beliefs, which "emphasize understanding the author's intended meaning” (Schraw 96), transactional theory connotes the activation of the text by the reader. Differing from the efferent stance in which the reader "disengages his attention as much as possible from the personal and qualitative elements in his response" (Rosenblatt 27, 1978), an aesthetic response demands that the reader actively involve all five senses as well as invest her/his emotions in the act of reading. In

Rosenblatt (1978) defines imagination as "the capacity of the human being to evoke images of things or events not present, and even never experienced, or which may never have existed" (32). effect, the reader is bringing life to the text through this investment. According to Rosenblatt (1978), "the text is merely an object of paper and ink until some reader responds to the marks on the page as verbal symbols" (23). The reader is an active participant in the creation of meaning as reading is seen as "an event in time" (12) in which the reader and the text come together suspending reality thus allowing the reader to enter the world of the text. Seen as a continuum of what the reader does while reading (See Figure 1), at the farthest efferent end, the reader is totally disengaged in the reading seeking only information that can be used after reading. At the aesthetic end of the continuum, the reader is actively involved in the text having her/his purpose fulfilled during the reading. The reader chooses which stance is needed at a particular time reading a particular text.

I was concerned particularly with the students' aesthetic reading of a text, which requires a spirit of exploration, an active imagination, and a willingness to experience a relationship with the text. "The word exploration is designed to suggest primarily that the experience of literature, far from being for the reader a passive process of absorption, is a form of intense personal activity” (Rosenblatt v, 1976). Exploration speaks of the reader's active involvement in the construction of meaning. Just as explorers do not just sit and wonder about the world beyond their walls, the reader cannot just sit and decode each letter and word. Both the explorer and the reader must get involved in their respective worlds. According to Rosenblatt (1976), a piece of literature does not stand by itself. The reader counts as much as the text as s/ he responds to the literature through exploring both the text and her/his personal response to the text. "The finding of meanings involves both the author's text and what the reader brings to it" (Rosenblatt 14, 1978). This investment of self brings about an aesthetic experience in which the reader brings individual meaning to the text. Furthermore, the topic to explore can change over time. As people change, their interests change as well. "The relation between reader and text is not linear. It is a situation, an event at a particular time and place in which each element conditions the other" (16). The transaction between text and reader depends both upon the text read and the particular situation in which the reader finds him or herself.

A second component to an aesthetic reading experience is an active imagination. Rosenblatt (1978) defines imagination as "the capacity of the human being to evoke images of things or events not present, and even never experienced, or which may never have existed" (32). She goes on to explain that imagination is the "essence of language" in that it enables the reader to see and deal with things that are not real. Here too, imagination requires the active participation of the reader as $\mathrm{s} /$ he is invited to involve all five senses-sight, hearing, touch, smell, and taste-in the very real creation of the world within the text. Imagination is what allows the reader to know the characters in a book so well that s/he could recognize them should they meet on a street corner. When a reader is

Efferent

Aesthetic

Figure 1. Rosenblatt's (1978) Theory of Reader Response Efferent/Aesthetic Reading Continuum 
so immersed in a text that s/he becomes virtually hypnotized, "anything else that might enter into awareness-a physical sensation, a noise, will be shut out, as he attends only to what the symbols before him bring into consciousness" (Rosenblatt 53, 1978). As one's senses are involved in the text, they are no longer attuned to the surrounding world; the reader is immersed in an in-depth aesthetic reading experience.

The third element of aesthetic reading is the willingness to experience relationship with the text. The reader's attention to the text activates certain elements in her/his past experience-external reference, internal response-that have become linked with the verbal symbols. Meaning will emerge from a network of relationships among the things symbolized as he senses them (Rosenblatt 11, 1978). In creating meaning from a text, the reader brings all of her/his background experience; every book read; every event, person, place, or thing to the reading. This generates myriad connections between text and reader, thus building a strong relationship. Again, the text does not stand alone, as "built into the raw material of the literary process itself is the particular world of the reader" (11). Furthermore, Rosenblatt explains that the text may change the reader as it leads him or her to reevaluate assumptions and prior associations. As has been seen, aesthetic reading requires the reader to make connections with the text. The reader then takes responsibility for choosing the appropriate response to those connections knowing that $\mathrm{s} /$ he may choose to reject or accept each one. Just as we decide which personal relationships in which to be involved, the reader does the same in building a relationship with the text.

\section{How My Students Constructed Meaning through Visual Spatial Activities}

This study took place in a middle school located in a small, urban center in northeast Ohio. The school has approximately 600 students of which $32 \%$ are African American, $2 \%$ are multi racial, and $65 \%$ are White. In addition, $57 \%$ of the students in this school are classified as economically disadvantaged, and 19\% are students with disabilities. The class had ten students, five African American and five White, seven male and three female. Their fifth-grade teachers identified these students, now in sixth grade, as struggling readers. The Dean of Students for the school indicated that the fifth-grade teachers had been asked to recommend no more than 20 students, based on reading ability, for a class that would receive extensive remediation in the hopes that their scores on state-mandated tests would improve.

In an effort to become part of the everyday classroom experience of the students, I began working with the class on the first day of school. By immersing myself in the culture of the classroom early on, I believe I obtained the trust of the students gaining the advantages as delineated by Patton (1990). The students came to see me as a visiting teacher within the classroom. In this capacity, I taught lessons on a weekly basis many times co-teaching with the classroom teacher.

The entire study involved the students reading and responding to a series of four short stories, "Eleven" (Cisneros, 1992), "The Use of Force" (Williams, 1938), "All Summer in a Day" (Bradbury), and "Chanclas" (Cisneros, 1984), each story taking approximately two days spread out over four weeks. The lessons were framed by the Structured Reading Lesson (Glasgow) including before, during, and after reading activities. This provided a "continuity of various instructional activities" as well as insured that the students were actively involved in "reading, writing, listening, speaking, and viewing" thus promoting a transactional approach to reading instruction (Rosenblatt 9, 1983).

On the first day of teaching the stories, students were instructed in frontloading activities (Glasgow). The purpose of frontloading (pre-reading) strategies is to actively engage the student "in understanding the purpose for reading a text" (10). As a frontloading activity, students first engaged in an activity called Brainstorm and Categorize, a derivation of List-GroupLabel (Taba), in which they were given a word central to the meaning of the story and asked to brainstorm as many words as they could about this term. They then created categories for the words. These lists were put on chart paper and posted on a wall as a reminder. This activity tapped into their prior knowledge as well as set them up for a major theme in the story. Next, students were asked to create a Symbolic Reading Representation (SRR) (Edmiston) about a time when they experienced this same concept or theme from the story. As this strategy previously proved effective in 
As an after-reading strategy and in response to the text read, students were given free choice as to

how they represented what they learned from the story. They were instructed to "create something that represents what the story means to you" in any way they wished. tapping into emotions when reading a work of fiction (Baer), it proved to be as effective when recreating a personal memory. Students were given construction paper and glue and instructed to think about a time when something similar happened to them. They also created a small graphic of themselves and placed it in the picture representing where they were as they thought about this event. As a group, we discussed the images created. Students were encouraged to share their pictures, talk about

the memory they recreated, and discuss where they had placed themselves in the pictures. In addition, students shared their feelings about their pictures and the recreated memories.

On the second day of reading each story we reviewed the categories of words students created as well as had further discussion about the images created during the SRR (Edmiston) activity. The purpose of doing this was to review the previous day's activities thus bringing to mind the feelings attached to their images. Students were asked to write about another significant moment in their lives that corresponded to another theme or concept from the story. I chose the themes and/or concepts for discussion according to the content of the given short story. Time was given for sharing their writing. Students were then given a copy of each story on which to follow along as I read aloud. Listening-while-reading both improves reading fluency and helps maintain student interest, especially for struggling readers (Carbo; Rasinski).

During-reading activities "help the students read constructively, use a range of transactions appropriate to the task, and capture personal responses to the text” (Glasgow 11). As a during-reading activity, students were involved in creating a Speaking Tableaux (Enciso, Edmiston, \& Colabucci). I stopped reading at a critical moment in the action in order to create the Speaking Tableaux. Students chose a character to represent and, after assuming a pose from the moment chosen, verbalized what they saw and heard from the perspective of the character. Either the teacher or I recorded what the students said and read this back to them after completing the activity.

As an after-reading strategy and in response to the text read, students were given free choice as to how they represented what they learned from the story. They were instructed to "create something that represents what the story means to you" in any way they wished. Their choices were unlimited for, as I learned from the above-mentioned pilot studies, students can create meaning in multiple forms, and I didn't want to limit their choices. For example, they could create a model, a three-dimensional picture, draw a sketch, or use any other means to show what the story meant to them. Various art supplies including markers, crayons, colored pencils, a variety of papers, and two different types of clay were supplied for their use. Students were allowed at least 30 minutes to complete their representations. After completing their projects, students were instructed to write about what they had created. Students answered two questions: 1) What did you create? 2) Why did you create this? This writing served two purposes. First, it helped them remember what they created and, second, it was used as a talking point in the ensuing interviews.

Having completed their projects, all students present were interviewed using the questions contained in Table 1 . The interviews were fluid in nature as individual follow-up questions were frequently asked depending on the responses of the students. Time was spent viewing the videotapes (see below), and students were asked questions about what they were doing at that particular time.

Data collection included videotaping the students during the entire process. This was done through setting up a video recorder on a tripod in a front corner of the classroom. As this was a small class containing only ten students, this provided an image of the entire class. The videotapes of the second day in which they created their projects were used to interview the students. Interviews were done through the use of "stimulated recall" (Smagorinsky \& Coppock) in which I watched the videotape with 
Table 1. Interview Questions

1. Explain what you created.

2. What matters most in your creation?

3. What are you doing here? (Asked while viewing videotape.)

4. What was going through your mind as you were creating your project? (Asked while viewing videotape.)

5. What parts of the story were you thinking about?

6. Talk about .... (Depended on what was happening in the videotape.)

7. Did this story remind you of anything?

8. Could you hear, see, feel, smell, taste anything from the story while you were creating the project and thinking about the story?

individual students, simultaneously interviewing them through discussion of why the student chose to do what $\mathrm{h} /$ she created and the thinking processes involved. The purpose of stimulated recall is to allow the student "to explore the range or processes recalled" (292). In the process of interviewing the students, they were also asked to tell me what mattered most in their projects. This question served as an effective tool to encourage deeper thinking as well as prolonged discussion. The focus of the interviews was on the students' process of creating their chosen projects as well as the finished products.

This study also made use of a constant-comparative methodology (Glaser \& Strauss) as data were analyzed in order to search for emerging patterns and themes in the student interviews, projects, and writing. In the constant-comparative approach "the researcher attempts to saturate the categories-to look for instances that represent the category and to continue looking and interviewing until the new information obtained does not further provide insight into the category" (Cresswell 151, 1998). I began with the stages as defined in A Taxonomy of Aesthetic Response (Sebesta, Monson, \& Doces Senn) and then modified these stages into categories as the data required. Table 2 defines these categories and gives samples of student responses from "Eleven" (Cisneros, 1992).

\section{Findings from the Study}

- Students constructed meaning through visual spatial activities by making sense of the stories read.
Throughout this study, students consistently recalled the events, character(s), or plots of the short stories. Burke (2001) refers to these as story elements and speaks to their importance in building understanding of a text. All of the students began a discussion of their projects by first talking about the story and how their model or drawing represented some aspect of the text. Students also used their projects to help them sequence the events of the story. Williams (2002) supports the importance of sequencing when she asserts, "knowledge of text structure helps students discover what is likely to be most relevant for understanding the story" (126). Students also based all of their responses solidly within the texts. This confirmed Rosenblatt's (1978) contention that while the reader's response to a text is personal, it is ultimately based in the text. It was also obvious throughout this study that these students understood the texts read. In an age of standardized tests, educators often put aside more aesthetic responses In an age of standardized tests, educators often put aside more aesthetic responses to literature, as the pressure to recognize and memorize story elements is paramount. This study shows, however, that educators can encourage student choice and more visual spatial responses to literature and the students can still learn those very same things so important to passing state mandated tests. to literature, as the pressure to recognize and memorize story elements is paramount. This study shows, however, that educators can encourage student choice and more visual spatial responses to literature and the students can still learn those very same things so important to passing state mandated tests. In addition, all of the students first constructed meaning through recollecting the text in order to then construct meaning in a more abstract form moving beyond the text to either their own lives or to the world-at-large. 
Table 2. Adaptation of a Taxonomy of Aesthetic Response with Student Examples

\begin{tabular}{|c|c|}
\hline & Student Example from "Eleven" \\
\hline $\begin{array}{l}\text { Category 1: Recollections (Evocation, recreation, or } \\
\text { elaboration of emotions, attitudes and/or events) } \\
\text { 1. Students construct meaning through a transaction } \\
\text { with the text that evokes a recollection, response, } \\
\text { and/or reaction to some aspect of the text. } \\
\text { 2. Students construct meaning through a transaction } \\
\text { with the text that evokes an imaginative elaboration } \\
\text { of characters, events, and/or objects. }\end{array}$ & $\begin{array}{l}\text { 1. Nick: } \\
\text { The main thing I was thinking of was that she said that } \\
\text { inside the sweater sleeves smelled like cottage cheese and it } \\
\text { was all sweaty and germy. That's gross. } \\
\text { 2. Nick: } \\
\text { From the story, she doesn't sound very stubborn. At first I } \\
\text { thought she was stubborn but then she didn't sound } \\
\text { stubborn. I don't know. I think she was afraid of the teacher } \\
\text { and that's why she put the sweater on. }\end{array}$ \\
\hline $\begin{array}{l}\text { Category 2: Associations (Alternatives such as comparing, } \\
\text { contrasting the original evocation) } \\
\text { 3. Students construct meaning through a transaction } \\
\text { with the text by associating some aspect of the story } \\
\text { to their own lives. } \\
\text { 4. Students construct meaning through a transaction } \\
\text { with the text by associating some aspect of the story } \\
\text { to other texts or media. }\end{array}$ & $\begin{array}{l}\text { 3. Mike: } \\
\text { Like I've been accused of something before and it really was } \\
\text { somebody else's and she was like, like in the situation that } \\
\text { she was in, too. } \\
\text { 4. Sierra: } \\
\text { It kind of reminded me of April Mendez (a character in } \\
\text { another story). Because she lived somewhere she didn't } \\
\text { want to be. And I like that there picture. And I liked how she } \\
\text { kind of stuck up for herself but at the end she went through, } \\
\text { she got everything, right? Because, remember in the story } \\
\text { she said, well 'I can't wait until lunch because I can just } \\
\text { take it off and throw it over the fence or throw it away in the } \\
\text { trash can.' That's what kind of what April wanted to do but } \\
\text { instead she just stepped up and she knew what she had to } \\
\text { deal with it. She probably got a new air freshener or } \\
\text { something, but she lived with it. }\end{array}$ \\
\hline $\begin{array}{l}\text { Category 3: Generalizations (Reflective thinking that } \\
\text { results in hypothesizing, synthesizing, evaluating, and/or } \\
\text { theorizing) }\end{array}$ & $\begin{array}{l}\text { Nick: } \\
\text { Ohhhhhh, ugh. I thought to myself that if I was in that } \\
\text { picture I would have probably threw it. If my teacher said, } \\
\text { put it on, I'd be like, getting away from it. Wouldn't you? }\end{array}$ \\
\hline
\end{tabular}

- Students constructed meaning through visual spatial activities by making connections between the text and their own lives or some other media.

Many of these students made strong personal connections with either a character or an event in one or many of the stories. Keene and Zimmerman (1999) refer to these as text-to-self and text-to-text connections as the reader either finds him/herself within the text or some similarity between texts. The authors state that good readers "independently and purpose- fully recall information and experiences relevant to what they are reading" (55). Making connections requires the reader to be actively involved with the text in that they are connecting something from the story to something from their own life experiences. Pressley (2002) states, "having knowledge is one thing, using it is another (271). These students took their knowledge of their own lives or another text and made connections with the texts read for this study. While educators have learned to use pre-reading 
activities to build prior knowledge thus enhancing these kinds of connections, this study showed yet another way to do this through an after reading strategy, responding to literature through visual spatial activities.

- Students constructed meaning through visual spatial activities by elaborating on the story.

When encountering something that made no sense to them, the students in this study would add some defining details from their own lives to help explain what was happening. Elaboration has to do with embellishing the text by bringing new information to the text thereby giving it a fuller dimension to enhance understanding (Wilhelm, 1997). In this study the students elaborated on objects, characters, or events from the texts. While staying within the text the students used their background knowledge to bring new information to the text to help them better understand it. Elaboration can also enhance comprehension of a text. Enciso (2004), discussing the link between drama and visualization, spoke of this kind of elaboration as an enhancement of comprehension. Although she referred to this as accompanying visualization and drama, this study shows that this can also happen when visualizing through creating visual spatial projects.

- Students constructed meaning through visual spatial activities by using mental imagery to create some aspect of the text thereby making generalizations beyond the text and themselves to the world-at-large.

When discussing their projects, students would at times make generalizations based on the text and their projects. These generalizations would move beyond the text and their own connections with the text to some kind of statement related to a greater understanding that could be applied to the world at large. Their project took on an abstract quality in that it represented some emotion or greater understanding that could apply to others. In effect, the students first made a mental image of some emotion or understanding of the text then translated that into a concrete model or image. In discussion they would then verbalize this more abstract understanding. According to Gambrell and Bales (1986), using mental imagery when reading provides a framework upon which readers can organize and remember text and helps readers to integrate information across text. In this study students took those abstract mental images, created concrete models or pictures, and used these to build further understanding of the story from which they made generalizations.

- Students constructed meaning through showing empathy with a character or situation in a story by sharing and/or understanding the feelings or physical sensations depicted.

Students would frequently show empathy with a character through their discussions about their visual spatial projects. This might be done through paying particular attention to the facial expressions on a model or drawing of a character. Eisner (1990) asserts that "art informs us about things that we didn't have the opportunity to experience directly” (34). By using visual spatial projects, these students were able to share the experiences of the characters within the stories. Expressions of understanding a character's feelings would often be expressed in the interviews or their These generalizations would move beyond the text and their own connections with the text to some kind of statement related to a greater understanding that could be applied to the world at large. states that "we participate in the story, we identify with the characters, we share their conflicts and their feelings" (75). As a student expressed empathy with a character from a story, s/he was, in effect, identifying with the feelings expressed by the character in response to the situation in the text. The difference in this case is that the visual spatial projects acted as a catalyst to this kind of response.

- Visual spatial activities helped these students explain how they constructed meaning.

In the interviews, the students would often hold or refer to their models as they spoke. The models became a connection between the texts read and the meaning they made from the text. Eisner (1990) speaks of the power of art in helping build understanding. This study not only confirms his beliefs but adds the power of the visual spatial project in supporting the language of the student as they discuss the project and how it relates to the text. 


\section{Implications for the Language Arts Classroom}

Educators may use this research to support other kinds of responses to text rather than the more usual writing and tests taken after reading. This study suggests that sixth-grade struggling readers constructed meaning from a text in some very personally meaningful ways that will most likely not be revealed on a question-answer test format. The fact that they all recalled the events, character(s), and/or plot summaries of these stories suggests that their involvement in visual spatial activities did not hinder their recollection of the stories and it also gave them a basis for further meaning as they elaborated, made associations, and/or generalizations. Many people think

This study also showed that sixth-grade struggling readers are capable of constructing meaning in more in-depth ways than may be revealed through strict pencil and paper

\section{responses.} that this kind of response can lead to the reader making unsubstantiated conclusions from text, but this study showed that meaning was solidly based in the text. This study also showed that sixth-grade struggling readers are capable of constructing meaning in more in-depth ways than may be revealed through strict pencil and paper responses. While beginning by recalling plot

details, many of them also made associations and generalizations beyond the texts. Restricting response to one acceptable way could limit the imagination and creativity of the students. Allowing students to choose how they will respond may well open up avenues of meaning that are far more interesting and validating for the student.

Language arts teachers could expand their understanding of the link between language and the arts. As was done throughout this study, students were encouraged to respond to literature through various art forms. This allowed these students to be more creative and utilize their imaginations in their response than if they were limited to writing. Most middle schools are structured in multiple period days with students changing classes every 40 to 50 minutes and there is little connection between classes and teachers. I believe, however, that there is a strong connection between literature and the arts and that the language arts and art teachers should work together thereby encouraging students to respond to texts in artistic forms and also respond to art in a more eloquent verbal form as they are both expressive forms of communication.

Teachers should allow students some choice in texts and response to texts within their classrooms. For the purposes of this study, all of the students read the same stories at the same time. Ideally, they would have each chosen a story to read. They did, however, have a choice as to how they would respond to the texts read. I believe it is vitally important to allow and encourage student choice in all classrooms. The fact that they each chose a medium to use to respond to a text did allow them to exercise their own individuality. Narrowing response to one particular mode can stifle creativity and imagination as well as limit response (Eisner, 1990). Students consistently expressed how much they enjoyed and valued the ability to choose how they responded to the stories. Part of teaching, with careful and sensitive guidance, is allowing students to explore and discover on their own. If, as Rosenblatt (1978) believes, literature is read and experienced differently for each person, then we need to allow students some choice in what they read and how they will respond to that which was read.

\section{Conclusion}

The students' ability to construct meaning from these short stories through visual spatial activities showed a real depth and breadth of understanding. These struggling readers learned that they have insights into texts that include recalling story elements, making associations to themselves and to other texts, and making generalizations beyond the texts. They learned that they could enjoy reading when given a choice as to how they will respond to what they read. They were excited about discussing their projects and how they understood the stories. Much like Shamatee, their projects were bridges of meaning between the text and their discussions. As they held their models in their hands, they expressed a depth of meaning that thrilled both the students and me. It is my hope that this study will support and encourage 
other educators to take this same leap and allow their students the chance to show them what they know through similar experiences.

Allison L. Baer is an assistant professor of Literacy at Western Michigan University. Her research interests include struggling adolescent readers and multiple ways of knowing. She is an avid reader of young adult literature and shares that love with her students, frequently turning them on to some of her favorite authors. Having recently received her doctorate from Kent State University, she is grateful to ALAN for funding her dissertation study, allowing her to open students' literature minds through visual, spatial activities.

\section{Works Cited}

Armstrong, Thomas. "Making the Words Roar." Education Leadership, 61, (2004): 78-81.

Bradbury, Ray. The Stories of Ray Bradbury. New York: Knopf, 1980.

Cisneros, Sandra. The House on Mango Street. New York: Vintage, 1984.

Cisneros, Sandra. Woman Hollering Creek: And Other Stories. New York: Vintage, 1992.

Cox, Carole, \& Many, Joyce E. "Toward an Understanding of the Aesthetic Response to Literature. Language Arts, 69, (1992): 28-33.

Cresswell, John W. Qualitative Inquiry and Research Design: Choosing among Five Traditions. Thousand Oaks, CA: SAGE Publications, 1998.

Eisner, Elliot W. "Implications of Artistic Intelligences for Education." Artistic Intelligences: Implications for Education. Ed. W. J. Moody. New York: Teachers College Press, (1990). 31-42.

Enciso, Patricia, Edmiston, Brian, \& Colabucci, Linda. "Opening Texts and Re-Engaging Lives: Image, Word, and Education." Paper presented at the meeting of the National Council of Teachers of English. 20 November, 2004.

Gambrell, Linda B., \& Bales, Ruby J. "Mental Imagery and the Comprehension-Monitoring Performance of Fourth- and FifthGrade Poor Readers." Reading Research Quarterly, 21, (1986): 454-464.

Glaser, Barney G., \& Strauss, Anselm I. The Discovery of Grounded Theory: Strategies for Qualitative Research. New York: Aldine Press, 1967.

Glasgow, Jacqueline (Ed.). Strategies for Engaging Young Adult Readers: A Social Themes Approach. Norwood, MA: Christopher-Gordon, 2005.

Greene, Maxine. Releasing the Imagination: Essays on Education, the Arts, and Social Change. San Francisco: Jossey Bass, 1995.
Guthrie, John T., \& Alao, Solomon. "Engagement in Reading for Young Adolescents." Journal of Adolescent \& Adult Literacy, 40, (1997): 438-447.

Guthrie, John T. \& Davis, Marcia H. "Motivating Struggling Readers in Middle School through an Engagement Model of Classroom Practice." Reading and Writing Quarterly, 19, (2003): 59-85.

Ivey, Gay, \& Broaddus, Karen. "'Just Plain Reading': A Survey of What Makes Students Want to Read in Middle School Classrooms." Reading Research Quarterly, 36, (2001): 350377.

Keene, Ellin Oliver, \& Zimmerman, Susan. Mosaic of Thought: Teaching Comprehension in a Reader's Workshop. Portsmouth, NH: Heinemann, 1997.

National Endowment for the Arts. "Reading at Risk: A Survey of Literary Reading in America (Research Division Report \#46). Washington, DC: U.S. Government Printing Office, 2004.

Park, Barbara. Mick Harte was Here. New York: Random House, 1996.

Patton, Michael Quinn. Qualitative Evaluation and Research Methods (2nd Ed.). Thousand Oaks, CA: SAGE Publications, 1990.

Pressley, Michael. (2002). Reading Instruction that Works: The Case for Balanced Literacy. (2nd Ed.), New York: Guilford, 2002.

Rosenblatt, Louise M. Literature as Exploration (4th Ed.) New York: Modern Language Association, 1983.

Rosenblatt, Louise M. Making Meaning with Texts: Selected Essays. Portsmouth, NH: Heinemann, 2005.

Sebesta, Sam L., Monson, Dianne L., \& Doces Senn, Helene. "A Hierarchy to Assess Reader Response." Journal of Reading, 38 (1995): 444-450.

Smagorinsky, Peter. "Multiple Intelligences in the English Class: An Overview." English Journal, 84 (1995): 19-26.

Smagorinsky, Peter, \& Coppock, John. "Cultural Tools and the Classroom Context: An Exploration of an Artistic Response to Literature. Written Communication, 11 (1994): 283-310.

Wilhelm, Jeffrey D. "Reading is Seeing: Using Visual Response to Improve the Literary Reading of Reluctant Readers. Journal of Reading Behavior, 27 (1995): 467-503.

Wilhelm, Jeffrey D. "You Gotta BE the Book": Teaching Engaged and Reflective Reading with Adolescents. New York: Teachers College Press, 1997.

Wilhelm, Jeffrey D. Reading IS Seeing: Learning to Visualize Scenes, Characters, Ideas, and Text Worlds to Improve Comprehension and Reflective Reading. New York: Scholastic, 2004.

Williams, William Carlos. The William Carlos Williams Reader. New York: New Directions. 1938.

Williams, Joanna P. "Using the Theme Scheme to Improve Story Comprehension." Comprehension Instruction: ResearchBased Best Practices. Ed. C.C. Block \& M. Pressley. New York: Guilford. (2002). 126-139. 